\begin{tabular}{|c|c|c|}
\hline \multirow{3}{*}{$\begin{array}{l}\text { EREM 73/2 } \\
\text { Journal of Environmental Research, } \\
\text { Engineering and Management } \\
\text { Vol. } 73 \text { / No. } 2 \text { / } 2017 \\
\text { pp. } 41-51 \\
\text { DOl 10.5755/j01.erem.73.2.18806 } \\
\text { @ Kaunas University of Technology }\end{array}$} & \multicolumn{2}{|c|}{$\begin{array}{c}\text { Analysis of Air Emissions and Greenhouse Gases in Woody } \\
\text { Biomass Production Chain }\end{array}$} \\
\hline & Received 2017/06 & Accepted after revision 2017/07 \\
\hline & \multicolumn{2}{|c|}{ Crossef http://dx.doi.org/10.5755/j01.erem.73.2.18806 } \\
\hline
\end{tabular}

\title{
Analysis of Air Emissions and Greenhouse Gases in Woody Biomass Production Chain
}

\section{Laurynas Virbickas, Irina Kliopova-Galickaja}

Kaunas University of Technology, Institute of Environmental Engineering

Gedinimo str. 50, Kaunas, Lithuania

Corresponding author: virbickaslaurynas@gmail.com

Laurynas Virbickas, Kaunas University of Technology, Institute of Environmental Engineering

Gedinimo str. 50, Kaunas, Lithuania

The whole world is trying to increase energy production from renewable energy sources. Biomass, mainly solid fuel (e.g. wood chips, sawdust, etc.), takes first place in Lithuania's efforts to increase energy production from renewables. There are a lot off studies about minimization of greenhouse gases (GHGs) during biomass combustion for energy production due to biogenic $\mathrm{CO}_{2}$. Unfortunately, such aspects as biofuel production, including biomass collection in harvesting sites, delivery to special interim sites, processing, produced biofuel transportation to combustion plants is rarely estimated in this studies. A considerable amount of diesel fuel is used within these processes by various mechanisms (e.g., skidders, tractors, crushers, chippers, etc.); therefore woody biomass production and delivery processes have significant environmental impact to air quality and climate change due to air emissions $\left(\mathrm{CO}, \mathrm{NO}_{\mathrm{x}}, \mathrm{NMVOC}, \mathrm{PM}, \mathrm{NH}_{3}\right)$ and $\mathrm{GHGs}\left(\mathrm{CO}_{2}, \mathrm{~N}_{2} \mathrm{O}, \mathrm{NH}_{4}\right)$ from off-road and road mobile sources.

This paper presents the method of evaluation and results of analysis of material and energy flows of wood chips production from traditional raw materials - firewood and forest logging waste (residues). It was estimated that up to 0.038 toe of diesel fuel is used for one toe of produced woody biomass, incl. over $52 \%$ - for biofuel delivery to combustion plant; $0.293 \mathrm{~kg}$ of air emissions and over $22.5 \mathrm{~kg}$ of GHGs are emitted to the air during production of one tonne of wood chips. Results of comparison analysis show that in case of biofuel production from logging residues, volume of GHGs is $57 \%$ higher in comparison to wood chips are produced from firewood. 
Several recommendations how to minimize significant environmental impact due to usage of logging residues to energy purposes are presented in article.

Received environmental indicators can be successfully used for further detailed life-cycle assessment of woody biomass production and usage for alternative energy.

Keywords: biofuel, biomass, forest logging residues, air emissions, greenhouse gases, production chain, renewable energy.

\section{Introduction}

Biomass carbon neutrality has been a long time debated issue. Considering that neutrality is reached by the fact that carbon returned to the atmosphere as a result of biomass burning and will again be absorbed by trees may lead to an error in accounting for carbon-based emissions (Haberl et al., 2012). An extensive and fascinating way to comprehend the accumulative impact and the grade of sustainability of a product like wood biofuels, which are supposed to decline the effect of energy use on the environment. At present, wood is commonly considered as a carbon-neutral resource. Heavy discussions in the science research changed the point of view on the government level. It was considered that if wood biomass is not managed properly it can lose it's name as carbon neutral by means of sustainable practices (Benoit, 2016).

In ensuring the overall greenhouse gases (GHGs) reductions, all stages in a biomass supply chain must be evaluated with respect on generated emissions. Using different methodologies and default values for calculating GHG balance and carbon sinks could lead to different conclusions rather than for example better understanding of changes in consumption and production in carbon footprint calculations (Van Dam et al., 2010, Levihn, 2014). Another point is that various biomass production scenarios may result in carbon footprint for wood products to vary widely (Newell \& Vos, 2012).

The methodology for the evaluation of potential of biofuel production in Lithuania and the corresponding model was created by the researches from Regional Energy Development Laboratory of the Lithuanian Energy Institute. They evaluated both volume of wood fuel harvesting and forest logging residues (unused portion of wood and bark left on the ground after trees' feeling, e.g. tops, broken pieces, and unmerchantable species). The simulation showed that in case of increasing use of potential logging residues by approx. $10 \%$, production volume of chopped wooden biomass chips could increase by approx. 1 mil. $\mathrm{m}^{3}$ per year, and thus, volume of produced wooden chips will be increased twice as much compared to 2013 (Dzenajaviciene et al., 2013). It was evaluated that up to 4.25 mil. $\mathrm{m}^{3}$ per year of different wood waste can be used for biofuel production in Lithuania, incl., up to $18 \%$ - forest logging residues, 39\% - firewood, and $43 \%$ - balance wood, which is commonly used for chipboards and paper production (it can be used for energy purposes in case of absence of another demand or due to economic aspect) (Dzenajaviciene et al., 2013).

Wood fuel can be divided into two main categories: processed (e.g. wood briquettes, pellets, etc.) and unprocessed (e.g. traditional firewood, pressed forest residues, wooden chips and sawdust). Unprocessed fuel is a wood fuel, which was only cut (crushed) and packed during processing, but its other properties don't change.

Several environmental risks are associated with the removal of logging residues from forest and use as a biofuel, e.g., biodiversity loss, physical damage to forest soils (due to stumps removal), and air pollution (from mobile and stationary sources) (Giuntioli, et al., 2015). Earth and stones are often taken along with the forest logging residues and can broke shredders and crushers. Besides, efficiency of combustion process decreases volume of ashes increases due to usage such type of biofuel.

Evaluating the carbon neutrality, the most effective forest cleaning method is the one when minimally fulfils the requirements, in other words, the one which shows equal or slightly higher carbon reserves compared to 
harvesting residue in non-use mode (Repo et al., 2015). The main technological processes of wood chips production from the firewood or forest logging residues are the follows: collection with special mechanisms (tractors, skidders, and forwarders) and delivery to special storage place (within or near the forest), chipping with mobile chippers (crushers) (disc, drum or screw), wood chips transportation to biofuel combustion plant for energy production (Vares et al, 2007).

It was evaluated that chipping is the most expensive and at the same time the most negative environmental impact creating action across the wood supply chain (Spinelli, 2009). Another crucial importance is calculation of capturing market adjustments and a large geographic scope when measuring the carbon implications of biomass energy policies (Daigneault et al., 2012).

Evaluation of air emissions and GHGs during wood chip production and delivery to energy production company is one of the essential condition for the environmental impacts assessment (EIA) and comparison of different types of energy production (Eero at al., 2014). Therefore, it's necessary to carry out a number of analyses for the evaluation of inputs and outputs flows and calculation of relative environmental indicators for every wood chips production and supply chain. Environmental impact of wood chip production depends on the used raw materials (firewood or forest logging residues), mechanism (skidders, tractors, chippers, crushers, etc.), trucks, characteristics of produced biofuel, etc. For example, fraction size of chipped material is very important from environmental impact point of view. Researcher from Belgium evaluated that if the diameter of produced chips increases from 4 to $16 \mathrm{~cm}$ (by factor 4), $\mathrm{CO}_{2}$ emission per $1 \mathrm{MWh}$ of energy production decreases by factor 7 (Van Belle, 2006). One of the main forestry tasks in area of production of biofuel or raw materials for biofuel is to select most proper conditions for different types of biofuel production (locality, climate, relief, etc.) and forestry planning. Most of this has been done in northern Europe, where it is better accessible wood stocks and a well-developed forestry system (Eero at al., 2014).

There are little specific studies, made in Lithuania, about harvesting wood for energy, for example, what kind of machinery is using for delivery, chipping of forest logging residues, environmental impact of such activity. Biomass producers inform that mainly the same tractors are used both for log and forest logging residues delivery out of tree feeling to log wood storage areas (tractors with self-loading trailers and forwarders (skidders). Forwarders use more fuel in comparison with tractors, in this case, cost-price increases significantly. Tractors with self-loading trailers are the most optimal machinery.

Logistics is a crucial aspect for the evaluation of energy balance of biofuel production and combustion processes. Fuel (energy) consumption for the delivery of wood residues or/and wood chips depends on particle size of biofuel, density of chips and technical characteristics of track.

Briefly, there are a lot of studies from area of forest $\mathrm{CO}_{2}$ absorption, extraction of $\mathrm{GHGs}, \mathrm{CO}_{2}$ from biomass combustion plants were made, but there is a lack of researches and information about life-cycle-assessment (LCA) of energy production from different types of biomass (both log wood and forest logging residues). The main goal of this investigation firstly is to evaluate air emissions and GHGs during woody biomass production, used widely applied mechanisms in Lithuania, and to make comparative analysis for the usage of 2 types of raw materials: traditional firewood (from log wood) and forest logging residues. Received environmental indicators will be used for further evaluation step - LCA.

\section{Materials and methods}

The analysis was done, evaluating main material and energy flows of wood chips production within ordinary Lithuanian biofuel Production Company. In 2015, about 43.2 thousand $\mathrm{m}^{3}$ of firewood and forest logging waste were used for wood chips production within this company.

Environmental impact assessment (EIA) was focused on the evaluation of significant environmental aspects - consumption of diesel fuel and direct impact to air due to emissions and GHGs from stationary and mobile sources during biofuel (wood chips) production processes, incl., log wood delivery to log wood storage site, forest logging waste collection and delivery 
to the same storage site, raw materials chipping, and produced wood chips transportation to the combustion plant for heat energy production.

Monitoring of used machineries, incl. evaluation of its technical data was the first step of analysis with purpose to evaluate inputs and outputs of technological processes and to create material and energy flows diagram. Received absolute environmental indicators (e.g. diesel fuel consumption (liters hour ${ }^{-1}$ or tonnes year ${ }^{-1}$ ), volume of air emissions (tonnes year ${ }^{-1}$ ), volume of $\mathrm{GHGs}$ (tonnes year-1)) were used for the evaluation of relative environmental indicators $\left(\mathrm{EI}_{\mathrm{r}}\right)$, which are usually used for the comparison analysis. $\mathrm{EI}_{\mathrm{r}}$ were calculated according to the following two equations (Kliopova et al., 2016):

$$
E I_{r}=X_{i}(t) \times P_{b}(t)^{-1}
$$

$$
E I_{r}=X_{i}(t) \times R(t)^{-1}
$$

where

$i$ is input or output flow; $X_{i}(t)$ is the quantity characteristic of this input or output flow per analyzed period, e.g. amount of diesel fuel (tonnes year $\left.{ }^{-1}\right) ; P_{b}(t)$ is the volume of produced biofuel (wood chips) per analyzed period, e.g. tonnes year-1 or $P_{b}(t)$ is the energetic volume of produced biofuel (wood chips) in tonnes oil equivalents per analyzed period (toe year-1); $R(t)$ is the amount of consumed raw materials per analyzed period, e.g. $\mathrm{m}^{3}$ year ${ }^{-1}$ or tonnes year ${ }^{-1}$.
Evaluation of air emissions during wood chips production (collection, delivery to storage site, and chipping) and produced biofuel transportation to energy production company was carried out according to the method, presented in EMEP/EEA air pollutant emission inventory guidebook - technical guidance to prepare national emission inventories (EMEP/EEA, 2016). Air emissions from the combustion and evaporation of fuel in all types of mobile sources could be evaluated according to the following equation:

$$
\mathrm{E}_{\mathrm{p}}=\mathrm{FC} \times \mathrm{EF} \times 10^{-6}
$$

where

$\mathrm{E}_{\mathrm{p}}$ - emission of pollutant (CO, NMVOC, NOx, TSP or PM, $\mathrm{NH}_{3}$ ), tonnes; $\mathrm{FC}$ - diesel fuel consumption, kg per year, $\mathrm{EF}$ - specific emission factor for off-roan machinery or road transport, $\mathrm{g} \mathrm{kg}^{-1}$ of used diesel fuel (see Table 1).

Methodology for the evaluation of GHGs from the combustion and evaporation of fuel is presented IPCC Guidelines for National Greenhouse Gas Inventories. Volume of GHG is calculated according to the following equation (IPCC, 2006):

$$
\mathrm{GHGs}=\mathrm{FC} \times \mathrm{Q} \times \mathrm{EF} \times 10^{-6}
$$

where

GHGs: $\mathrm{CO}_{2}, \mathrm{CH}^{4}$ or $\mathrm{N}_{2} \mathrm{O}$, while burning various fuels, tonnes; FC - fuel consumption, tonnes; $Q$ - Low heating value of fuel (GJ tonne-1), in case of diesel

\section{Table 1}

Specific emission factors for evaluation of air emissions during biomass wood chips production and transportation to energy production company, $\mathrm{g} \mathrm{kg}^{-1}$

\begin{tabular}{c|c|c|c|c|c}
\hline \multicolumn{1}{c|}{ Specific emission factors } & CO & NMVOC & NOx & TSP or PM & NH \\
\hline 1 & 2 & 3 & 4 & 5 & 6 \\
\hline${ }^{1}$ Off-roan machinery & 7.673 & 1.997 & 28.471 & 0.943 & 0.008 \\
\hline${ }^{2}$ Road transport & 7.58 & 1.92 & 33.37 & 0.94 & 0.013 \\
\hline
\end{tabular}

Information sources:

'EEA/CORINAIR, 1.A Combustion, 1.A.4 Non road mobile machinery 2016, Tables 3.1, fuel - diesel, sector - Forestry.

EEA/CORINAIR, 1.A Combustion, 1.A.3.b.i-iv Road transport 2016, Tables 3.5 - 3.7, category - HDV. 
fuel - 43.07 GJ tonne ${ }^{-1}$; EF - specific emission factor ( $\mathrm{g} \mathrm{GJ}^{-1}$ of fuel) (see Table 2).

\section{Table 2}

Specific emission factors for evaluation of air emissions during biomass wood chips production and transportation to energy production company, $\mathrm{g} \mathrm{GJ}^{-1}$

\begin{tabular}{c|c|c|c}
\hline \multicolumn{1}{c|}{ Sector: } & $\mathrm{CO}_{2}$ & $\mathrm{CH}_{4}$ & $\mathrm{~N}_{2} \mathrm{O}$ \\
\hline 1 & 2 & 3 & 4 \\
\hline Road transport & 74100 & 3.9 & 3.9 \\
\hline Off-road machinery & 74100 & 4.15 & 28.6 \\
\hline
\end{tabular}

Information sources:

IIPCC, 2006, Volume 3 "Energy", chapter 3 "Mobile combustion”, tables 3.2.1 - 3.2.2 (fuel type - diesel, sector - road transport.

'IPCC, 2006, Volume 3 "Energy", chapter 3 "Mobile combustion”, table 3.3.1 (fuel type - diesel, sector - off-road sources - Forestry).

\section{Results and discussion}

The initial environmental assessment aggregated information about the company's environmental impact. For this purpose, the most suitable way is to analyse material and energy flows and to create materials and energy balance. Energy production from wood chips material and energy flows are presented in Fig.1. Four cycles are presented in this diagram: extraction of main raw materials (forest harvesting), wood chip production from firewood and/or forest logging residues, produced wood chip transportation to biofuel combustion plant and biofuel combustion for energy production.

\section{Monitoring of wood chips production}

Technical information about widely used machinery within woody biomass production, incl. evaluated $\mathrm{El}_{\mathrm{r}}$ in area of diesel fuel consumption is presented in Table 3 . In analysed company, tractor MTZ-82 is used both for the log wood and forest logging residues delivery from the harvesting site to the temporary log wood storage site (e.g., the access road). From the economic point of view, maximum distance for log wood delivery to storage site could be less than $1 \mathrm{~km}$.

Two chippers are used for biomass chipping and chips wood production: rather new one - Pezzolato PTH 900/1000 and old one - Doppstadt AK 421 (see Table 3).

\section{Fig. 1}

Energy production from forest residues: material and energy flows diagram

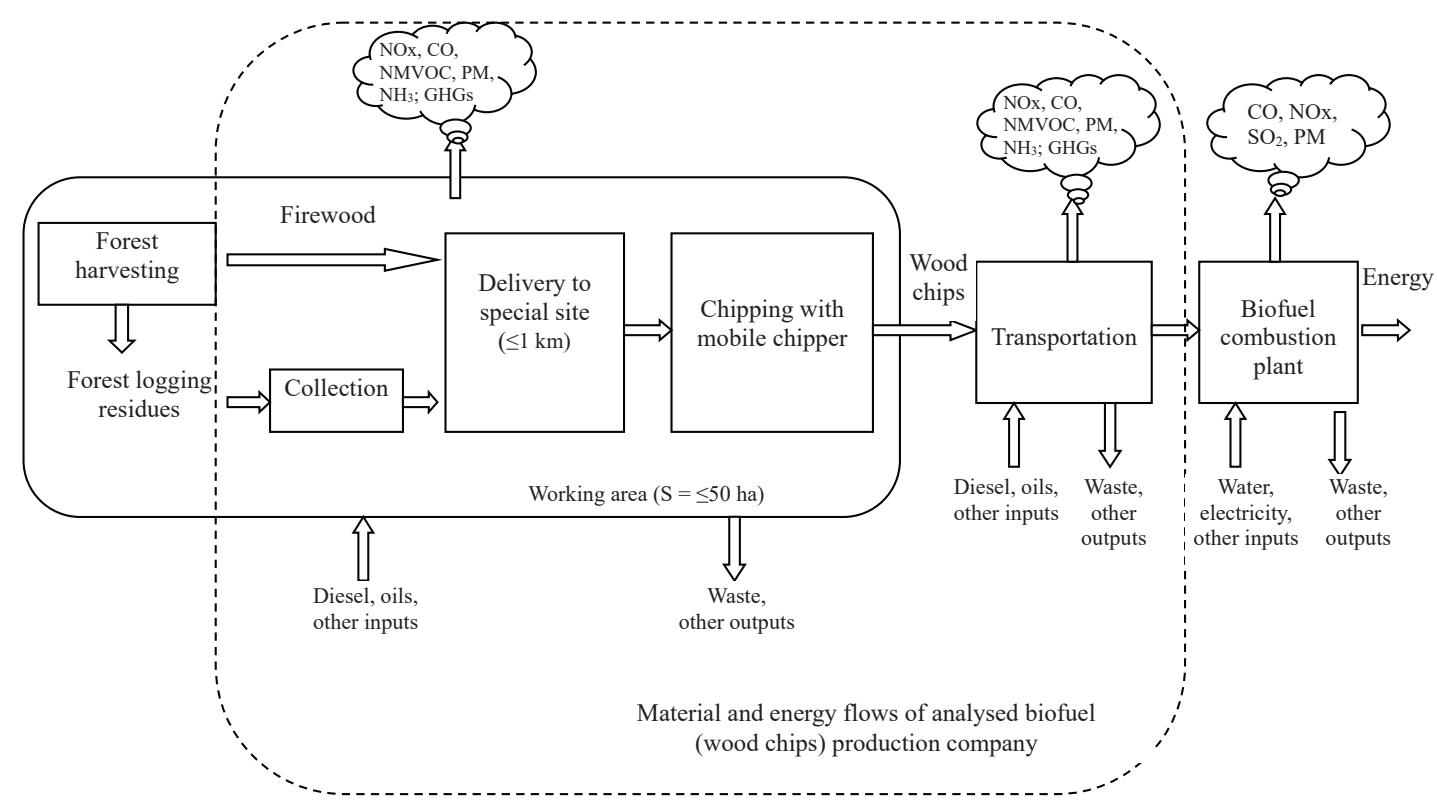




\section{Table 3}

Technical data of machinery, used in analyzed company for wood chips production and delivery

\begin{tabular}{|c|c|c|c|}
\hline Machinery & Model & Comments & $\begin{array}{c}\text { Diesel fuel consumption } \\
\text { (El } I_{r} \text { was evaluated using equation 2) }\end{array}$ \\
\hline 1 & 2 & 3 & 4 \\
\hline Tractor & MTZ-82 & $\begin{array}{l}\text { Maximum distance of wood } \\
\text { haulage way (a forest } \\
\text { track) - } 1 \mathrm{~km}\end{array}$ & $\begin{array}{l}{ }^{1} 0.57 \text { liters for } 1 \mathrm{~m}^{3} \text { of firewood; } \\
{ }^{2} \text { up to } 2.286 \text { liters for } 1 \mathrm{~m}^{3} \text { of logging } \\
\text { residues }\end{array}$ \\
\hline Drum chipper & $\begin{array}{l}\text { Pezzolato PTH } \\
900 / 1000\end{array}$ & $\begin{array}{l}\text { Capacity - up to } 300 \mathrm{~m}^{3} \text { of } \\
\text { log wood per hour }\end{array}$ & $\begin{array}{l}{ }^{1} 1.5 \text { liters for } 1 \mathrm{~m}^{3} \text { of firewood; } \\
{ }^{2} 1.143 \text { liters for } 1 \mathrm{~m}^{3} \text { of logging residues }\end{array}$ \\
\hline Chipper & $\begin{array}{l}\text { Doppstadt AK } 421 \\
\text { (1998) }\end{array}$ & $\begin{array}{l}\text { Capacity - } 36 \mathrm{~m}^{3} \text { of lops, log- } \\
\text { ging residues, etc. per hour }\end{array}$ & $\begin{array}{l}11.58 \text { liters for } 1 \mathrm{~m}^{3} \text { of firewood; } \\
21.143 \text { liters for } 1 \mathrm{~m}^{3} \text { of logging residues }\end{array}$ \\
\hline $\begin{array}{l}\text { Truck with special hy- } \\
\text { draulic trailers ( } 5 \text { units) }\end{array}$ & Volvo FH-12 & $\begin{array}{l}\text { Capacity }(V)-36 m^{3} \text { of } \\
\text { biofuel }\end{array}$ & 140 liters per 100 km \\
\hline
\end{tabular}

Information sources: 'Company's data; ${ }^{2}$ Dzenajaviciene et al., 2013.

Volvo FH-12 trucks with special hydraulic trailers with capacity $36 \mathrm{~m}^{3}$ of biofuel (wood chips) or approx. 28 tonnes per trailer are used for biofuel transportation to combustion plant. From the economic point of view, maximum distance for produced biofuel delivery to combustion plant could be less than $100 \mathrm{~km}$.

The following produced biofuel characteristics were evaluated in the Agrochemical Research Laboratory of the Lithuanian Research Centre for Agriculture and Forestry and were used for further evaluation of $\mathrm{El}_{\mathrm{r}}$ :

density of wood chips is 0.78 tonnes $\mathrm{m}^{-3}$;

low heating value of wood chips made of firewood is 0.158 toe $\mathrm{m}^{-3}$, or $6.63 \mathrm{MJ} \mathrm{m}^{-3}$, or $8.52 \mathrm{MJ} \mathrm{kg}^{-1}$;

low heating value of wood chips made of forest logging residues is 0.142 toe $\mathrm{m}^{-3}$, or $5.93 \mathrm{MJ} \mathrm{m}^{-3}$, or $7.62 \mathrm{MJ} \mathrm{kg}^{-1}$.

According to the company's data, the price of wood chips is distributed as follows:

Cost-price of raw materials (log wood) - 60-70\%;

Cost-price of production (collection, delivery, processing) - 10-20\%;

Cost-price of transportation to combustion plant (-s) - 10-20\%;

Profit $-5-10 \%$.
Price varies depending on type of log wood, the distances, the market price, etc. In 2015, average market price of biofuel (wood chips) in Lithuania during heating period was 147.78 Eur toe-1, excl. VAT (Baltpool 2016).

Variation of biofuel (wood chips and woof pellets) market price in Lithuania during 2016-2017 heating period is presented in Fig. 2.

\section{Material and energy flows}

In analysed company in 2015, 31.92 thousand tonnes of wood chips were produced from 21.6 thousand $\mathrm{m}^{3}$ of firewood and the same volume of forest logging residues. The energetic volume of produced wood chips - 258350.4 GJ or 6171.77 toe. Over 268 thousand tonnes of diesel fuel ( $\approx 9703.8 \mathrm{GJ}$ or 231.82 toe) were consumed, incl., over $52 \%$ - for biofuel transportation to combustion plants, approx. 25\% - for biomass chipping and rest amount - for biomass delivery to special site.

Using experimental monitoring data and data of company's annual financial report, it was evaluated how much diesel fuel was used exactly for wood chips production made of firewood, incl. transportation (the results are presented in Fig. 3) and how much - for wood chips production made of logging waste 


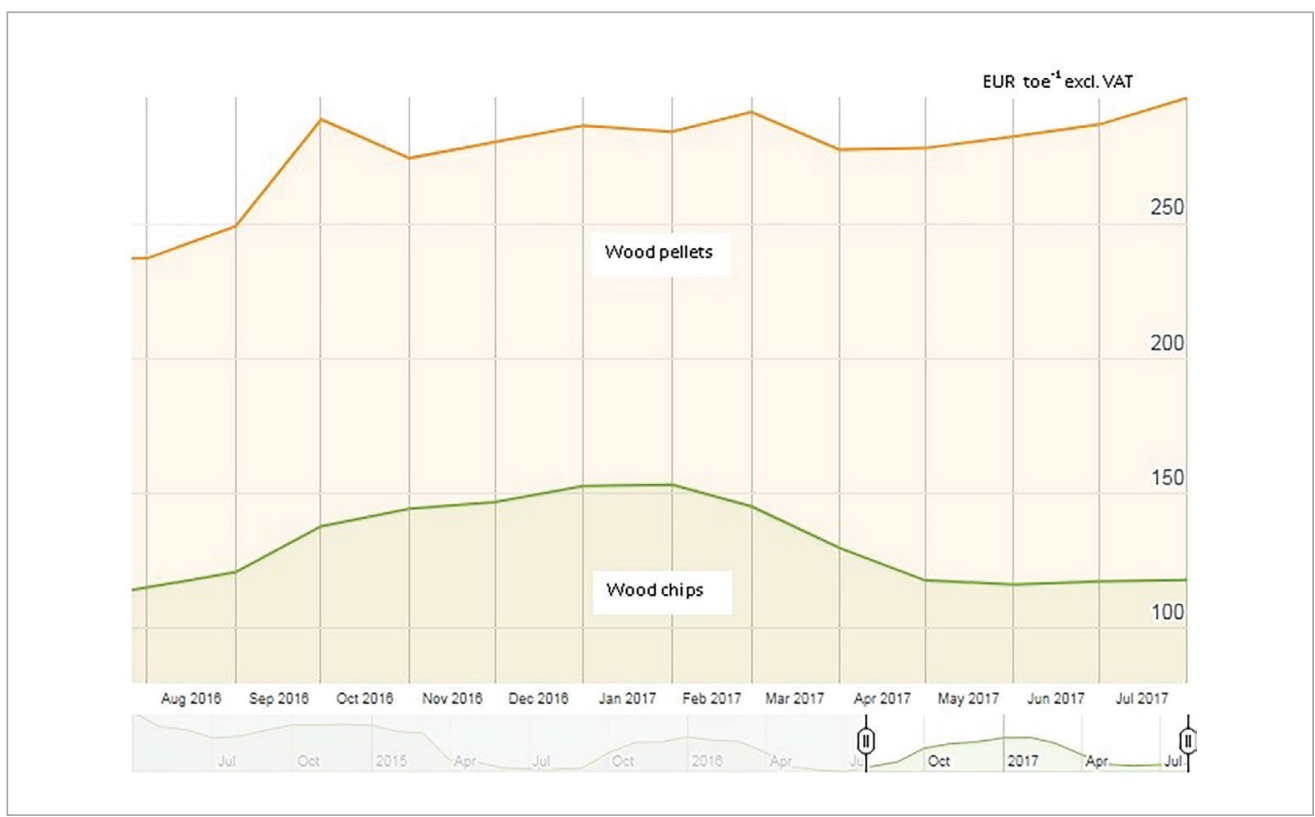

Fig. 2

Biofuel price in Lithuania in 2017 (Baltpool 2017)

\section{Fig. 3}

Material and energy flows of wood chips production from firewood and transportation to combustion plant (-s), units year-1 (company's data, 2015)

\section{Main inputs, units year-1}

Firewood $-21600 \mathrm{~m}^{3}$

Diesel fuel - 118396 liters $(99.453$ tonnes), incl. for transportation $61.895 \mathrm{t}$

Oil -70 liters

Hydraulic oil - 505 liters

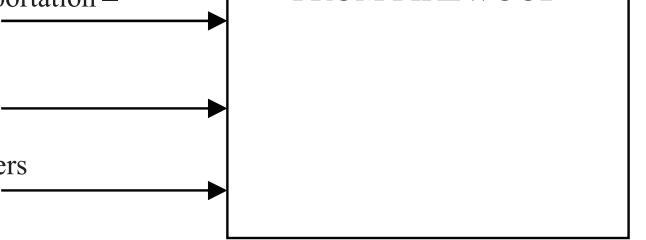

Main outputs, units year ${ }^{-1}$

Wood chips - 16800 tonnes (or 143136 GJ)

Waste (used oils, spare parts, etc.)

Air emissions, tonnes:

$\mathrm{NOx}-3.135$

$\mathrm{CO}-0.757$

NMVOC -0.194

PM -0.094

$\mathrm{NH}_{3}-0.0011$

GHGs, tonnes:

$\mathrm{CO}_{2}-317.402$

$\mathrm{CH}_{4}-0.017$

$\mathrm{N}_{2} \mathrm{O}-0.057$ (see Fig. 4). Fig. 4 Material and energy flows of analysed wood chips production from forest logging residues and transportation to combustion plant (-s), units year ${ }^{-1}$ (company's data, 2015)

Air emissions from mobile sources due to diesel fuel consumption for firewood and logging residues collection, delivery by tractor and chipping by mobile chippers were evaluated using equation 3 and specific emission factors for off-roan machinery (forestry). It was evaluated that 4.21 tonnes of emissions $\left(\mathrm{CO}, \mathrm{NO}_{x}\right.$, NMVOC, $\mathrm{PM}, \mathrm{NH}_{3}$ ) are emitted to the air during these processes.

Air emissions from mobile sources due to diesel fuel consumption for manufactured biofuel transportation 


\section{Fig. 4}

Material and energy flows of analysed wood chips production from forest logging residues and transportation to combustion plant (-s), units year ${ }^{-1}$ (company's data, 2015)

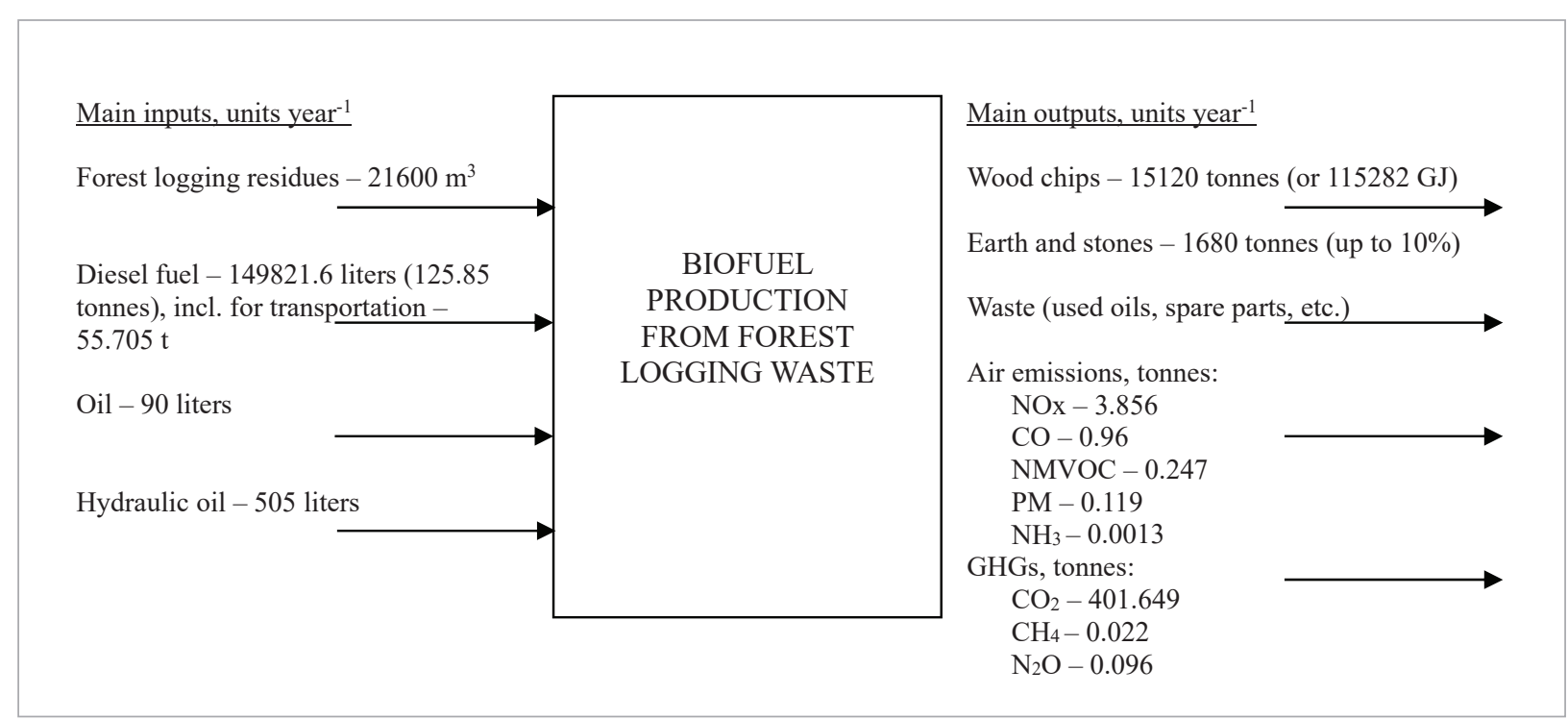

were evaluated using equation 3 and specific emission factors for road transport. It was evaluated that 5.154 tonnes of emissions (CO, NOx, NMVOC, $\mathrm{PM}, \mathrm{NH}_{3}$ ) are emitted to the air during wood chips transportation.

GHGs were calculated using equation 4 and specific emission factors from Table 2. It was obtained that 719.051 tonnes per year of $\mathrm{CO}_{2}, 0.039$ tonnes of $\mathrm{CH}_{4}$ and 0,152 tonnes of $\mathrm{N}_{2} \mathrm{O}$ are emitted to the air. The global warming potential (GWP) of $\mathrm{CH}_{4}$ is over 25 times bigger in comparison to $\mathrm{CO}_{2}$ equivalent (eq.), $\mathrm{N}_{2} \mathrm{O}$ gases is by 298 times bigger. Therefore, GWP of evaluated GHGs from wood chips production and transportation to combustion plant is 765,448 tonnes of $\mathrm{CO}_{2}$ eq. per year or over $124 \mathrm{~kg}$ per toe of energetic volume of produced wood chips.

\section{Results of comparison analyses}

Relative environmental indicators were calculated using equation 1 and 2. Comparison of such indicators for wood chips production from firewood and forest logging residues are presented in Table 4. The results of comparison analysis show that:

in case of evaluation of produced wood chips in mass units (in tonnes), producer consumes over $11 \%$ more biomass for biofuel production from forest logging residues in comparison to biofuel production from firewood (up to $1.429 \mathrm{~m}^{3}$ per tonne of wood chips), over $40 \%$ more diesel fuel (up to $8.323 \mathrm{~kg}$ per tonne of wood chips); approx. 37\% more emissions (up to $0.343 \mathrm{~kg}$ per tonne of wood chips) and over $40 \%$ more GHGs are emitted to the atmosphere;

in case of evaluation of energetic volumes of produced wood chips (in toe), producer consumes over $24 \%$ more biomass for biofuel production from forest logging residues in comparison to biofuel production from firewood (up to $7.848 \mathrm{~m}^{3}$ per toe of wood chips), over $56 \%$ more diesel fuel (up to 0.047 toes per toe of wood chips); approx. $54 \%$ more emissions (up to $1.883 \mathrm{~kg}$ per toe of wood chips) and over $57 \%$ more GHGs are emitted to the atmosphere.

The main reasons are following: usage unfit machinery for forest logging residues' collection, old and worn-out equipment for biomass delivery to special site, usage of old chippers, less low heating values in comparison with wood chips from firewood, etc.

\section{Possibilities to minimize environmental impact}

Volume of diesel fuel and thus environmental impact to the air can be minimized by applying Cleaner Production (CP) prevention methods for forest logging waste 
Table 4

$\mathrm{El}_{\mathrm{r}}$ of wood chips production from firewood and forest logging residues

\begin{tabular}{|c|c|c|c|}
\hline Relative environmental indicator & Dimension & Firewood & ${ }^{1}$ Forest logging residues \\
\hline 1 & 2 & 3 & 4 \\
\hline \multirow{2}{*}{ Biomass consumption for biofuel production } & $m^{3}$ tonne $e^{-1}$ & 1.286 & 1.429 \\
\hline & $m^{3}$ toe $^{-1}$ & 6.317 & 7.848 \\
\hline \multirow{2}{*}{ Diesel fuel consumption for biofuel production } & $\mathrm{kg}_{\text {tonne }}{ }^{-1}$ & 5.920 & $8.323(7.662)$ \\
\hline & toe toe $e^{-1}$ & 0.030 & $0.047(0.043)$ \\
\hline \multirow{2}{*}{$\begin{array}{l}\text { Total air emissions ( } \mathrm{CO}, \mathrm{NOx}, \mathrm{NMVOC}, \mathrm{SP}, \mathrm{NH}_{3} \text { ) during biofuel pro- } \\
\text { duction and transportation }\end{array}$} & $\mathrm{kg}_{\text {tonne }}{ }^{-1}$ & 0.249 & $0.343(0.317)$ \\
\hline & $\mathrm{kg}$ toe $\mathrm{e}^{-1}$ & 1.223 & $1.883(1.741)$ \\
\hline \multirow{2}{*}{$\mathrm{GHGs}\left(\mathrm{CO}_{2}, \mathrm{CH}_{4}, \mathrm{~N}_{2} \mathrm{O}\right)$ during biofuel production and transportation } & $\mathrm{kg}_{\text {tonne }}{ }^{-1}$ & 18.897 & $26.572(24.460)$ \\
\hline & $\mathrm{kg}$ toe $\mathrm{e}^{-1}$ & 92.845 & $145.971(134.367)$ \\
\hline
\end{tabular}

Comments:

'Figures in brackets are the evaluated indicators of disel fuel consumption, volume of air emissions and GHGs in case of the implementation of CP options for wood chips production from forest logging residues.

${ }^{2} Q$ of wood chips made of firewood is 0.158 toe $\mathrm{m}^{-3} ; \mathrm{Q}$ of wood chips made of forest logging residues is 0.142 toe $\mathrm{m}^{-3}$.

collection and for collected biomass chipping chines (Virbickas, 2015). Applying methodology of CP implementation within production companies (Staniškis at al., 2010), the feasibility analysis of CP proposals was carried out. It was evaluated that using special head for skidder with purpose to collect forest logging residues will allow increasing efficiency of this process by 5-10 $\%$, thus minimizing diesel fuel consumption per by $5 \%$ (till 2.172 litters per $\mathrm{m}^{3}$ of biomass). Besides, electronic engine control of new modern skidders and forwarders ensures low energy losses, while enhancing fuel economy. The implementation of new modern chipper for wood chips production from forest logging residues will allow minimizing diesel fuel consumption within this technological process by $22-27 \%$ (depends on model) (till 1.143 litters per $\mathrm{m}^{3}$ of biomass).

The implementation of suggested CP proposals will allow decreasing total volume of diesel fuel consumption for wood chips production from forest logging waste by approx. $8.5 \%$ (till 0.043 toe per toe of wood chips), in this case air emissions will decrease by $7.5 \%$ (till $1.741 \mathrm{~kg}$ per toe of wood chips), GHGs by $7.9 \%$ (till $134.367 \mathrm{~kg}$ per toe of wood chips). Nevertheless, environmental impact to the air will remain much higher than in case of wood chips production from traditional firewood (see Table 4).

\section{Conclusions and recommendations}

The results of literature analysis show that Lithuania has a big potential of biofuel production from forest logging residues: up to 780 thousand $\mathrm{m}^{3}$ year $^{-1}$ of logging waste could be used for the production of wood chips with approx. 111 thousand toe of energetic value. Environmental risks due to removal of logging residues from forest and use as biofuel associate with the biodiversity loss, physical damage of forest soils, and air emissions from mobile and stationary sources on all woody biomass production chain.

Main results of the evaluation of material and energy flows of wood chips production in ordinary Lithuanian biofuel production company:

optimal distance for delivery forest logging residues to special interim sites must be $\leq 1 \mathrm{~km}$;

optimal distance for transportation of woody biomass to combustion plant must be $<100 \mathrm{~km}$; 
density of wood chips is 0.78 tonnes $\mathrm{m}^{-3}$;

low heating value of wood chips made of forest logging residues is over 10\% lower in comparison with wood chips made of traditional firewood and amounts 0.142 toe $\mathrm{m}^{-3}$, or $7.62 \mathrm{MJ} \mathrm{kg}^{-1}$;

diesel fuel consumption for off-road purposes is up to $3.374 \mathrm{~kg}$ tonne $\mathrm{e}^{-1}$ of produced wood chips;

diesel fuel consumption for wood chips transportation to combustion plant - up to $3.684 \mathrm{~kg}^{\text {tonne }} \mathrm{e}^{-1}$ of produced wood chips and this indicator depends on distance to combustion plant;

amount of air emissions due to diesel fuel consumption is $0.293 \mathrm{~kg}_{\text {tonne }}{ }^{-1}$ of wood chips (or $1.517 \mathrm{~kg} \mathrm{toe}^{-1}$ );

GWP due to emitted GHGs from mobile sources is up to 765.448 tonnes of $\mathrm{CO}_{2 \text { eq. }}$ year ${ }^{-1}$ or $124.024 \mathrm{~kg}$ of $\mathrm{CO}_{2}$ eq. toe ${ }^{-1}$ of wood chips.

Comparison analysis of material and energy flows of wood chips production determined that diesel fuel consumption within all stages of biofuel production from forest logging residues and transportation to combustion plant, exceeds diesel fuel consumption

\section{References}

Baltpool (2016) Market of Lithuania energy resources. Available at: http://www.baltpool.eu/en/activity/ .

Daigneault A, Sohngen B, Sedjo R (2012) Economic Approach to Assess the Forest Carbon Implications of Biomass Energy. Environ. Sci. Technol. 46 (11): 5664-5671. https://doi.org/10.1021/ es2030142

Dzenajaviciene E F, Kveselis V, Tamonis M. (2013) Miško biokuro ištekliu potencialo ir gamybos modeliavimas / Forest resources potential of biofuels and production simulation. Energetika 59: 12-16. Available at: www.Imaleidykla.lt/ojs/index.php/energeti$\mathrm{ka} /$ article/download/2705/1537

Eero J, Olli-Jussi K, Juha L, Tapio R (2014) Greenhouse gas emissions of forest bioenergy supply and utilization in Finland. Renew. Sustain. Energy. Rev. 29: 369-382. https://doi.org/10.1016/j. rser.2013.08.101

EMEP/EEA Air pollutant emission inventory guidebook (2016). Available at: http://www.eea.europa.eu/publications/emepeea-guidebook-2016.

Giuntioli J, Caserini S, Marelli L, Baxter D, Agostini A (2015) Domestic Heating from Forest Logging Residues: Environmental Risks and Benefits. Journal of Cleaner Production 99: 206-216. https://doi.org/10.1016/j.jclepro.2015.03.025 for biofuel production from firewood in average by $56.7 \%$ or by $43.3 \%$ in case of applying CP options. Equipment optimization or modernization will allow decreasing diesel fuel consumption from 0.047 toe toe ${ }^{-1}$ of wood chips to 0.043 toe toe $e^{-1}$ and thus decreasing volume of air emissions and GHGs by over $7.5 \%$.

Recommendations for wood chips production from forest login residues:

It is necessary to properly assess the amount of logging residue in the harvesting site before their collection and usage for biofuel production, to evaluate economic and environmental aspects of this decision, especially in case of situation when distance between harvesting site and interim biomass processing site is $\geq 1 \mathrm{~km}$.

It is necessary to find an optimal scenario of power and energy consumption within used machinery (equipment), to optimize the work and to carry out a detailed life-cycle assessment of usage forest logging waste for energetic purposes. Received environmental indicators could be successfully used for further evaluation step - LCA.

Haberl H, Sprinz D, Bonazountas M, Cocco P, Desaubies, et al. (2012) Correcting a fundamental error in greenhouse gas accounting related to bioenergy. Energy Policy 45: 18-23. https:// doi.org/10.1016/j.enpol.2012.02.051

IPCC Guidelines for National Greenhouse Gas Inventories (2006). Available at: http://www.ipcc-nggip.iges.or.jp/public/2006gl/vol2.html.

Kliopova I, Baranauskaitè-Fedorova I, Malinauskienè M, Staniškis J, K (2016) Possibilities of increasing resource efficiency in nitrogen fertilizer production. Clean Technologies and Environmental Policy: 18(3): 901-914. https://doi.org/10.1007/s10098-015-1068-9

Levihn F (2014) CO2 emissions accounting: Whether, how, and when different allocation methods should be used. Energy 68: 811-818. https://doi.org/10.1016/j.energy.2014.01.098

Newell J P, Vos R. O (2012) Accounting for forest carbon pool dynamics in product carbon footprints: Challenges and opportunities. Environmental Impact Assessment Review 37: 23-36. https://doi.org/10.1016/j.eiar.2012.03.005

Benoit C (2016) CO2 Neutral Biomass Fuel: Life Cycle Analysis of waste to energy systems, a case study. University of British Columbia: 49. Available at:

Prada M, Martinez-Alonso C, Sanchez-Garcia S, Canga E (2015) 
Analysis of Three Forest Chippers: Productivity, Costs and GHG Emissions in Northern Spain. Journal of Cleaner Production 101: 238-244. https://doi.org/10.1016/j.jclepro.2015.03.066

Repo A, Ahtikoski A, Liski J (2015) Cost of Turning Forest Residue Bioenergy to Carbon Neutral. Forest Policy and Economics 57: 12-21. https://doi.org/10.1016/j.forpol.2015.04.005

Spinelli R, Visser R (2009) Analyzing and estimating delays in wood chipping operations. Biomass. Bioenerg. 33, 429-433. https://doi.org/10.1016/j.biombioe.2008.08.003

Staniškis J K, Stasiškienė Ž, Kliopova I \& Varžinskas V. (2010). Sustainable Innovations in Lithuania Industry Development and Implementation . Monograph. P. 314 (Lithuanian).

Van Belle J (2006) A Model to Estimate Fossil CO2 Emissions during the Harvesting of Forest Residues for energy - with an Application on the Case of Chipping. Biomass and Bioenergy 12 (30): 1067-1075. https://doi.org/10.1016/j.biombioe.2005.12.019

Van Dam J, Junginger M, Faaij, A. P. C (2010) From the global efforts on certification of bioenergy towards an integrated approach based on sustainable land use planning. Renewable and Sustainable Energy Reviews 14(9): 2445-2472. https://doi. org/10.1016/j.rser.2010.07.010

Virbickas $L$ (2015). Forest residues as a biomass for energy production. Master's thesis. P - 54

Vares V, Kask Ü, Muiste P, Pihu T, Soosaar S (2007) Biokuro naudojimo žinynas / Biofuel Handbook: 149 (Lithuanian). Available at: http://www.ena.tt/doc_atsi/biokuras.pdf

\section{Išmetamų oro teršalų ir šiltnamio efektą sukeliančių dujų analizè medienos biomasès gamybos grandinèje}

\section{Laurynas Virbickas, Irina Kliopova - Galickaja}

Kauno technologijos universitetas, Aplinkos inžinerijos institutas, Gedinimo g. 50, Kaunas, Lithuania

Visam pasauliui didinant energijos gamybą iš atsinaujinančiu energijos išteklių, pirmauja biomasès - kietojo kuro gamyba. Straipsnyje apžvelgiama esama situacija Lietuvoje, galimas biomasès potencialas. Medienos skiedros gamybos procesu monitoringas, nustatant žaliavos, energijos sąnaudas produkcijos vienetui ( $\mathrm{m}^{3}$ medienos skiedros) atliktas 2015 metais imoneje, kuri užsiima medienos skiedru gamyba iš malkinès medienos ir kirtimo atliekų ir pardavimu katilinèms Kauno regione.

Naudojant monitoringo duomenis, straipsnyje analizuojama ar tikrai Lietuvoje naudojamo atsinaujinančioji kietojo biokuro energija yra tokia „Žalia“ aplinkai, kaip pateikta daugumoje tyrimu, teigiančiu, kad deginant medieną i aplinką išsiskiria šiltnamio efektą sukeliančiu duju (ŠESD) kiekiai, kurie yra absorbuojami augalams augant. Tačiau visuose tyrimuose yra mažai vertinamas toks aspektas kaip biokuro gamybą, isk., biomasės paruošimą, surinkimą, gabenimą iki tarpinių aikšteliu, smulkinimą ir transportavimą iki biokurą deginančių irenginių. Visu šių procesų metu sunaudojamas dyzelinis kuras, ị aplinkos orą iš mobilių taršos šaltinių išmetami oro teršalai (CO, NOx, NMLOJ, KD, NH$\left.)_{3}\right)$ ir ŠESD $\left(\mathrm{CO}_{2}, \mathrm{~N}_{2} \mathrm{O}, \mathrm{CH}_{4}\right)$. Šio klausimo aktualumas dideja, kai vertinama skiedru gamyba iš miško kirtimo atliekų, pasižyminčiu mažesne žemutine šilumingumo verte.

Tyrime atlikta lyginamoji analizè, vertinant medienos skiedrų gamybos iš tradicinès malkinès medienos ir kirtimo atlieku poveiki aplinkos orui dèl dyzelinio kuro sąnaudu visoje biomasès gamybos grandinyje. Medienos akiedru gamybos ir transportavimo metu, biokurui naudojant miško kirtimo atliekas i aplinką išskiriama net 57 \% daugiau ŠESD (iki 145.971 kg per the (tona naftos ekvivalento) biokuro) nei naudojant malkinę medieną. Apibendrinus tyrimo rezultatus matyti, kad norint turèti kuo mažesni poveiki aplinkai ir pelningai vykdyti veiklą, biokuro gamyba iš miško kirtimo atliekų turi būti gerai pasverta ir organizuota, galbūt net papildomai remiama, persvarstant miško kirtimo atlieku panaudojimo strategiją. Būtina tęsti tyrimus ir atlikti pilną būvio ciklo analizę medienos biokuro gamybos ir naudojimo energijai gauti procesuose, nes tai itin svarbu šalims, kuriose biokuras yra populiariausia atsinaujinančios energijos rūšis.

Raktiniai žodžiai: biokuras, biomasè, miško medienos atliekos, oro emisijos, šiltnamio dujos, gamybos grandinè, atsinaujinanti energija. 